\title{
8 The search for a clear vision
}

I wonder, were you right then, or are you right now?

In whose interest is that change?

H.I.

In 2011, the first year of our fieldwork in Alexandria, Mukhtar and I met H.I., a man who proudly described himself as a poet - although he hadn't written anything for over ten years. H.I. was born in an Upper Egyptian village in the early 1970s. After completing his university education, he moved to Alexandria to work as a teacher of Arabic and Islamic religious education in a government school. He began writing at a young age. In 2002, he published his first volume of poetry. Then he fell silent as a poet. Every time we have met him since that day at the school, he has always told us: 'There is no clear vision.'

This chapter tells the story of H.I. and his poetry, and explores literary imagination and poetic aesthetics driven by an active search for firm certainties. It is the story of a difficult and at times confusing search for a clear vision in the context of Islamist movements that promote a utopian agenda of radical change but become involved in political arrangements and tactics in ways that can compromise their radical utopian purity. My argument in conversation with H.I. follows up directly from the argument I developed in conversation with Montaser Abdel Mawgoud in Chapter 7. There, I showed how a poetic search to explore and to think differently about spiritual certainties may offend powerful societal sensibilities. I also argued that a postmodern valorisation of uncertainty cannot be absolute; it depends on certainties and forms of trust that enable it. In this chapter, I argue that, conversely, a conservative search for certainty and clarity can involve much doubt and confusion. Its key points of friction lie elsewhere, however, as do the aesthetic and moral answers it strives to find. The different paths followed by H.I. and Montaser correspond with literary aesthetics and poetic techniques in important ways. And yet with their differences, they also share an important romantic common ground, and a structuring historical experience of defeated uprisings.

\section{Struggle}

In February 2012, we met H.I. for a first formal interview. He brought us his collection (diwan) of poems, mostly written in classical double verse. They have diverse topics, genres, and emotional tones. Religious-political nashids (hymns) mingle 
with conventional odes to father and mother, and melancholic lyrical explorations of the condition of living in an unclear and uncertain world. The book - or rather booklet - was published in a small print run, and has low-quality layout and printing. It has a price printed on the back cover, but it is unlikely that it would ever have been sold. Rather, it would be distributed by the poet himself as it was at our encounter. H.I. proudly handed to us a copy, and accompanied it with a signed dedication.

In the course of the interview, he walked us through his diwan. His way of presenting his work was decidedly subjective and autobiographic: he told us about the circumstances and poetic choices of each poem, linking them with his youth, education, literary socialisation, and his time in prison.

H.I.'s influential readings include Arabic classics, especially from the Abbasid period, twentieth-century classicists, and some (fewer) twentieth-century modernists. ${ }^{1}$ He also highlighted his religious education. He memorised the Qur'an at a young age and read religious books extensively. He was not involved in Islamist organisations, but was very interested in religious matters and discussions. In accord with the romantic baseline of twentieth-century modernism, he highlighted the lyrical, subjective grounding of his poetry:

All my poems are subjective, and I did not speak about the other, because I consider every verse of my poems a personal image of me, and a period of my life. If I want to refresh my memories, I look at my poems.

In his early poems, a melancholic tone prevails. The first lines of one of them, Where is the way out? (Ayn al-mafarr) is printed in part on the back cover of the diwan. It is the only poem in the collection that is not in 'amudi double verse but in taf'ila, modernist metred free verse. It begins as follows:

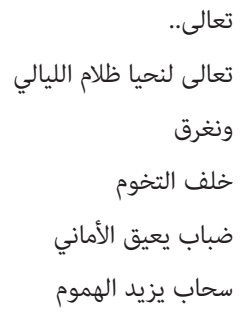

1 He mentioned by name Ilya Abu Madi, Ahmad Shawqi, Hafez Ibrahim, Abu l-Qasim al-Shabbi, al-Tijani Yusuf Bashir, Fakhri Abu l-Su'ud, AbdelSalam Ayun al-Sud, Badr Shakir al-Sayyab, AbdelMu'ti al-Hamshari, and Fawzi al-Ma'luf. 

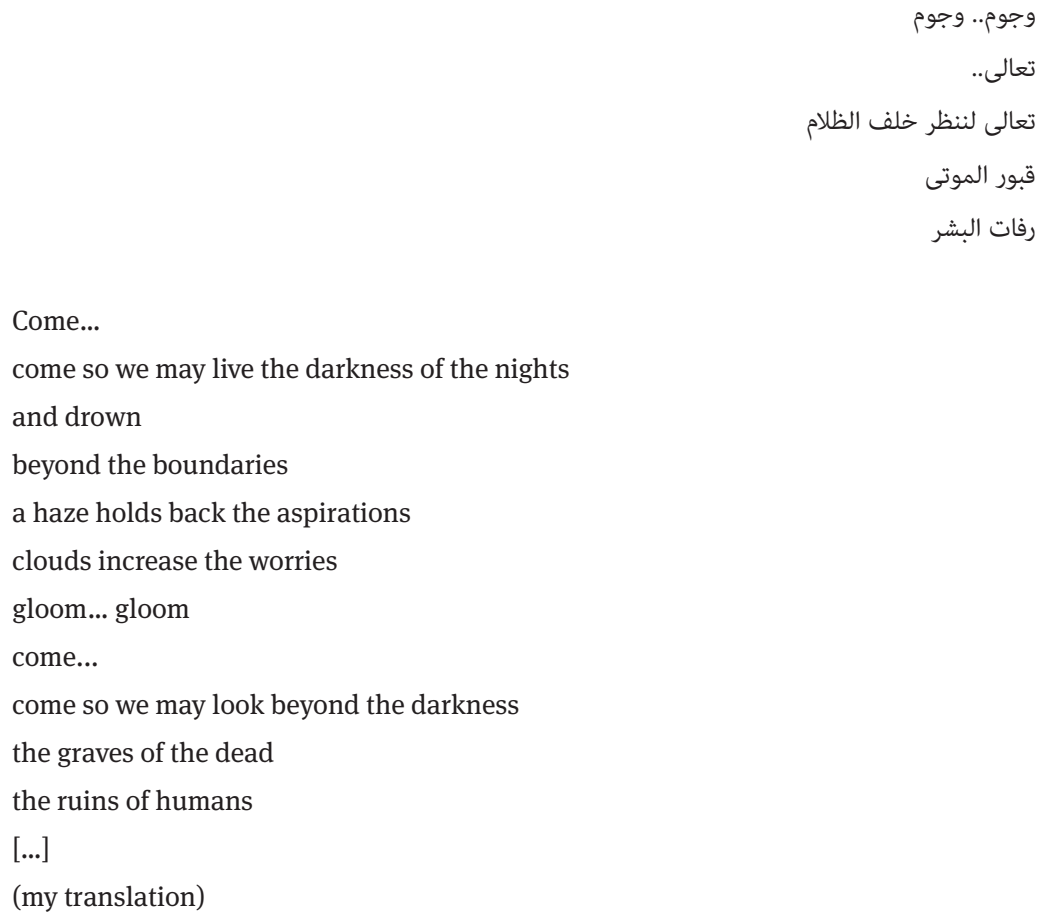

In the early 1990s, around the time when he wrote this poem, H.I. became involved in the literary life of Alexandria, frequenting cultural centres of the public-sector networks. But his career among Alexandria's literati was suddenly interrupted in 1994.

The early 1990s were a violent time in Egypt, marked by an Islamist insurgency that was centred in Upper Egypt. The leading movement in that insurgency was al-Gama'a al-Islamiya, literally 'the Islamic group'. ${ }^{2}$ The movement was involved in terrorist attacks and guerrilla warfare against the police, Christians, and tourists. The Egyptian regime fought the uprising heavy-handedly. A whole region was under curfew and restrictions of movement, while entire villages were demolished in acts of retaliation. The death toll of the insurgency exceeded 1,400. As many as 47,000 activists and sympathisers with the movement as well as uninvolved people were detained (Naguib 2009).

2 Despite the similarity of names, al-Gama'a al-Islamiya is not directly related to Jamaat-i Islami, a party founded by Abu A'la Maududi in British India in 1941. 
H.I. was not involved in the group. However, the movement was spearheaded by university students and graduates from Upper Egypt, and as a university graduate from the region he became a collateral victim of a campaign of collective suspicion and punishment.

This resulted in a traumatic experience of six years in prison, the details of which H.I. asked us not to discuss in this book. Instead, he allowed us to cite three poems (in my translation) that he composed during the time, in chronological order of composition. Following H.I.'s request, I do not provide any context.

$$
\begin{aligned}
& \text { وارفعوا الإسلام دينا } \\
& \text { دعوة المختار فينا } \\
& \text { سوف تنزاح الغواية } \\
& \text { قد بدا والحق غاية } \\
& \text { يا شبابا قد تسامى في } \\
& \text { نرتضي البغى إماما } \\
& \text { سطروا للحق بابا } \\
& \text { لفقوه وارتيابا } \\
& \text { الكفر فينا واستبد } \\
& \text { كي يهد الكفر هدا } \\
& \text { في الورى نور الهداية } \\
& \text { وارفعوا للحق راية } \\
& \text { قد بدا نور الصباح } \\
& \text { وانطلقنا للكفاح } \\
& \text { في ظلال وارفات } \\
& \text { كل وعد الحق آت في } \\
& \text { ذات وعد الحق فينا } \\
& \text { وارفعوا الإسلام دينا }
\end{aligned}
$$

$$
\begin{aligned}
& \text { شباب الحق } \\
& \text { يا شباب الحق هبوا } \\
& \text { وابذلوا الخير ولبوا } \\
& \text { يا شباب الحق صبرا } \\
& \text { ويكون العسر يسرا } \\
& \text { لا تقولوا قد يئسنا } \\
& \text { نحن جند الله لسنا } \\
& \text { يا شباب الحق هيا } \\
& \text { وأزيلوا عنه غيا } \\
& \text { لا تقولوا طال ليل } \\
& \text { ورفعوا القرآن نورا } \\
& \text { يا شباب الحق كونوا } \\
& \text { وانشروا العدل وقوموا } \\
& \text { لا تظنوا الليل يبقى واتثروا لعدل } \\
& \text { قد رأينا الحق حقا } \\
& \text { يا شباب الحق سيروا } \\
& \text { وعلى النهج استقيموا } \\
& \text { سوف يأتي النصر يوما } \\
& \text { فاذكروا الرحمن دوما }
\end{aligned}
$$

\section{The youth of Truth}

Move, the youth of Truth

Sacrifice for the right cause and search

Be patient, youth of Truth

Hardship will turn to ease and hold high the religion of Islam

for the call of the chosen one among us the temptation to sin will pass the aim of Truth comes to sight 
Don't say: we despaired

We are God's soldiers and won't

Up, the youth of Truth

Purge it from fabricated

Don't say: the night of unbelief

Raise the light of the Qur'an

Righteous youth, be

Spread justice and stand up

Don't assume that the night would last

We have truly seen the Truth

The youth of Truth, wander

Follow the straight path

One day victory will come

So always say the name of the Merciful
Oh youth that strives for victory

accept tyrants as leaders

mark a door for the Truth

errors and from doubt

is long and powerful upon us

to demolish unbelief to the ground

the light of guidance among mankind

and raise the flag of Truth

The morning light has just appeared and moved out to the struggle in blooming shades every promise of Truth will come true as Truth has promised to us and hold high the religion of Islam ${ }^{3}$

\section{Return}

[...]

How to find salvation, when corruption and wilfulness surround us?

When the good dropped its protection and the evil became our custom

Who brings tragedies and evils, and who heals our wound?

Arrows of disgrace began to hit from here and there

[...]

3 In addition to meaning truth and justice, al-Haqq is also one of the names of God. The poem is a nashid (hymn) for singing composed in a simple short-beat metre (فاعلاتن فاعلاتن or described in long (-) and short ( $\left.{ }^{(}\right)$syllables: $-^{-}--_{-} /-^{-}-$) that is good for singing and easy to memorise in a situation where no means of writing was available. 


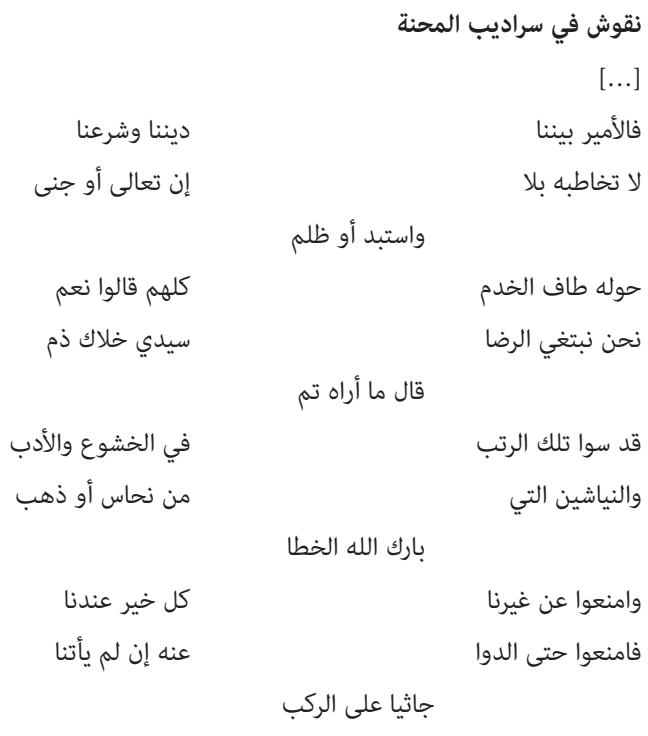

\section{Carvings in the catacombs of ordeal}

[...]

The commander among us is our religion and law

do not say 'no' to him

when he is arrogant or criminal

nor when he is a despot or oppressor

Around him the servants gathered

all of them said yes

we seek to be content

my lord, you are free of blame

he said: what I see, happens

They were the same: those ranks

in obedience and fine manners

and the military medals

made of gold and copper

God bless the steps

And ban from others

all good things we have

Even ban from him his medicine

unless he comes to us

bowing on his knees

[...] 


\title{
Silence
}

In 2001, H.I. returned to an ordinary civilian life, but his view of the world was shattered:

\begin{abstract}
I entered the prison with the feeling that people have principles, but at the end [...] I knew that interests are what moves people. No matter what a person's stance and appearances, he is ruled by private, personal interests. Everybody can become an oppressor and commit any crime you can imagine, and he can find a justification for his committing of the crime. Imagine the most recent parliament. We had books and pamphlets that declared that merely participating in elections was unbelief. And now they contradict themselves, and seats in the assembly and political positions became a part of religion. That's why I said in Puzzled questioning: 'In the name of principles and interests the traditions changed'. (باسم المبادىء والمصالح قد تغيرت السُنن) That’s concerning the religious current that changed its face for the sake of interest, and that made me ask myself: I wonder, were you right then, or are you right now? In whose interest is that change?
\end{abstract}

Soon afterwards, H.I. published his volume of poems. It was a matter of great importance for him: 'the first thing I thought of'. Then he stopped writing for over a decade. In the interview in February 2012, he was still hopeful that the revolution would at least allow for a thorough critical engagement with the Mubarak era. He had hopes to republish his small diwan, this time accompanied with a documentation of the circumstances in which it was written, because when it was published in 2002, it had been politically not possible to do that.

After ten years of silence as a poet, he still proudly identified as a poet, and insisted that he would make a comeback. But the time was not right:

Until now, there is no clear vision (ru'ya wadha), and I'm not able to see anything certain (thabta) so that I could know my point of view about it. So I can't write anything. [...] Now, worldly interests rule, so if I wrote now, I would write description of the nature or the sea.

The impact of literature ( $a d a b$ ) must be based on a clear message. If not, it will be mockery and not literature, it will be indecency (qillit adab).

H.I. explicitly understood $a d a b$ as the intersection of narrative or poetic texts and the cultivation of a conservative set of fine manners. And while he repeatedly identified as a lyrical and subjective poet, he also insisted that the subjective grounding of poetry had to result in a message, a clear vision. And yet according to H.I., such vision was nowhere around. The absence of that vision appeared to be grounded primarily in his painful encounter with militant movements and their failure to act by the principles they had once proclaimed. He had not given up his principles. The movement had. 
This became even more explicit in our next interview in January 2013. As we walked to a seaside cafeteria for the interview, we spotted graffiti calling for new demonstrations on the second anniversary of the revolution. H.I. commented bitterly: 'There was a revolution? All it has accomplished is public indecency.' As we sat down in the café, we asked if he had written anything new since our last meeting. He still had not:

If I wrote, I would only be attacking, and that is not my nature, because I'm for peace. [...] I had a lot of faith in the revolution, but now the revolution has turned into indecent exposure (il-thawra tila 'it 'awra). If I would write, it would be with irony, not seriously. Especially if I spoke about the Islamic current in particular.

The timing of H.I.'s critique of Islamist movements is remarkable. The 25 January revolution had resulted in what in the winter of 2012-2013 looked like the golden hour of Islamist politics. An Islamist president had been ruling Egypt for six months, and at that moment it still looked as if he would consolidate his rule. And yet H.I. saw the revolution as a confusing failure. He repeatedly spoke about the absence of certainties (thawabit) and positive change, but when we asked him what such change would involve, he was vague: 'I dream of radical change of society. But it has become impossible in every respect.'

'Haze' (dabab) was another word he used in conversations with us for the lack of clear vision - a word he had already used in his early poem Where is the way out? In both his poetry and our encounters with him, H.I. emerges as a man in search of principles and certainty who at the same time has a keen sensibility for uncertainty. His search for clear vision, it seems, has made him especially sensitive to the haze of the world he lives in. This sensibility made him principled enough that he would not overlook the hierarchies and inequalities within a movement that claimed to liberate humans from the yoke of other humans through their exclusive submission to the power of God. It also made him too principled to accept the pragmatic power games of Islamist movements after 2011. Indeed, it made him too principled to take any stance at all when all stances seemed ultimately tactical and pragmatic.

Instead, he told us, he lived in the past. He had no new poetry, but he brought us a pile of manuscripts and a cheaply printed book from the time of his youth that documented his literary becoming. He showed them to us with a sense of pride and fondness, and began reciting poems from a hardback diary dated 1410 H (c. 1992 CE). They tell about hope in a better future turning into confusion, about lovesickness, nostalgia for childhood, and inspiration. Next, he showed us a school notebook written in a childish handwriting. With a mixture of joy and nostalgia, he went through the pages of the notebook, stopped to recite a poem 
here and there. Often, he had to stop to read more carefully because the handwriting was not clear, passages had been crossed out or changed, or were out of metre. He told us:

Reading them makes one remember oneself when one wrote them. I like more my younger self when I wrote about everything. H.I. has changed. The vision has changed. The young writer was freer and more mobile, with less social pressure on him. But when I read old poems, I am surprised. I read them in a different way now. I find things that were buried inside me. Especially when there is a long period between writing and reading, it is like having learned to swim, and then going to the sea for the first time in a decade.

Mukhtar: With writing so important for you, how do you live without writing?

H.I.: I live in remembrance of the past.

\section{Comeback}

In 2013, H.I. had described himself as a nostalgic man living in the past, but the poetry he wrote in his youth already has a distinctly melancholic, even nostalgic tone. Melancholy and a sense of uncertainty and doubt appear a constant aspect of H.I.'s writings, but never to the exclusion of the confidence that there is a greater divine truth to follow. H.I.'s doubts have never concerned the possibility and existence of divine certainties. Rather, his 'puzzled questioning' is about how to live by them in an uncertain world.

It took four years until we would interview H.I. again. Finally, we met him in February 2017, and he had good news. He had made his long-awaited comeback. He had started writing again, and frequented literary gatherings in public-sector cultural spaces such as the Writers' Union. He had also begun publishing his work on social media, and was preparing a new volume that contained new poems as well as some old ones.

At our previous meetings, we had talked much about politics. Meanwhile, the situation had changed. Now, a heavy-handed military regime was clamping down on all opposition, and especially hard on Islamist opposition. H.I.'s history put him in a precarious position. Mukhtar and I therefore carefully avoided discussing politics with him this time. Even so, he appeared worried and evasive. He appeared afraid to say anything even vaguely political, but he was very keen to speak about his poetry. This circumstance made us pay attention to poetics and aesthetics in a way that we might not have done otherwise. Just as we learned from Montaser about the experimental aesthetics of exploring a changing world, 
from H.I. we learned about the aesthetic labour of searching for certainties in that same changing world.

We were curious to know what inspired him to start writing again, but he evaded our question. In the past, he had insisted that he would make a comeback only if he possessed a clear vision. Now, he still insisted there was no clear vision. And yet he had made a comeback, in terms of both writing and socialisation in a literary scene. Perhaps H.I. himself had no clear idea what had inspired him to write again; or perhaps he could give no answer that would be congruent with his insistence on clear vision as a condition to write. In the absence from an answer from H.I., Mukhtar suggested to me a likely answer: Facebook. Social media allowed him to act as a poet again, and to be recognised as one - which is inspiring. On the evening after our meeting, he posted online a photo of the three of us sitting in an up-market cafeteria not far from the sea in El Mandara, and soon received numerous words of appraisal from his online friends in the comments section.

He recited to us from memory one of his new poems, Enchainment (Hadith al-qayd, unpublished), a classical 'amudi poem. Enchainment is written in the same metre as his above-quoted Youth of Truth, but it is more complex in several ways. Its imagery is more nuanced and ambiguous, and it involves the intentional display of formal virtuosity. The poem has a difficult mono-rhyme -iq and is written in a long (tamm) variety of the classical metre of al-Ramal, described in the Arabic notation system as فاعلاتن فاعلاتن فاعلات (Al-Wasil 2015: 62-66). ${ }^{4}$ It makes use of the flexibility of the metre to create minor rhythmic variations within the poem, displayed here (from left to right) in a scheme of long (-) and short ( $\left.{ }^{\circ}\right)$ syllables:

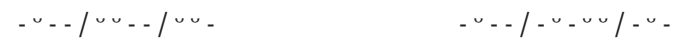

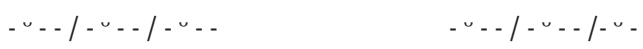

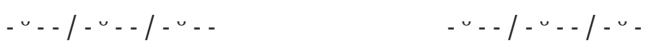

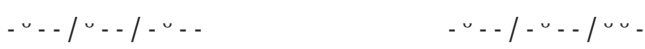

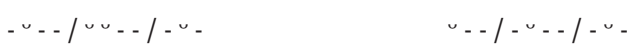

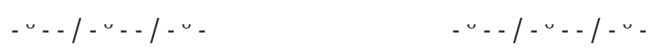

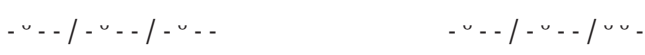

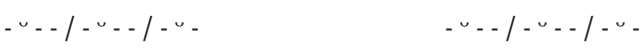

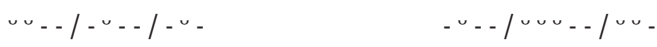

4 In comparison, the above-cited Youth of Truth uses a shortened (majzu') variety of the same metre, and has an easy rhyme - $a$ that is also not maintained throughout. 


$$
\begin{aligned}
& \text { حائر وحدي تَعنَّ في الطريق } \\
& \text { أم كلانا في أسى الدنيا غريق تعريق } \\
& \text { عاثرات مل يعد فيها بريق } \\
& \text { والأماني سُكرُها ليس يفيق ينا برنيق } \\
& \text { شربنا العشق صمتًا في الرحيق يقيق } \\
& \text { هذه الآمال والدنيا تضيق } \\
& \text { في طريق مُوحشٍ لسنا نفيق } \\
& \text { نفحة من سرّ ماضينا العتيق } \\
& \text { رُبَّ حرٍ وهو في القيد وثيق من ماضينا لعتيق }
\end{aligned}
$$

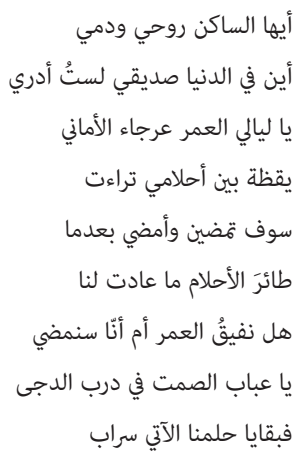

Oh dweller in my spirit and blood

I am at loss alone, stumbling along my path

Where in the world is my friend, I don't know

or are we both drowned in the grief of this world

Oh nights of lifetime with their lame longings

stumbling with no spark left in them

A moment of waking between the dreams made itself seen

while the drunkenness of the longings does not awake

You will pass and so will I after

we drink silently love's exquisite wine

Oh bird of dreams, these hopes

did not return us, while the world turned bleak

Will we awake to life or will we pass

on a desolate path without waking up

Oh torrents of silence on the trail of darkness

grant some of the secret of our ancient past

Thus the remains of our future dream are a mirage

Many a free man is firmly enchained

After reciting the poem to us, H.I. pointed at its melancholic tone, which in fact dominates his lyric poetry: a confusing wandering in darkness coupled with transient love and an illusion of freedom are contrasted with the divine certainties that dwell 'in my spirit and blood', glimpses of awakening (a repeated phrase), and a hope invested in 'our ancient past'. When he published it on his Facebook page a year later, he described it as a piece of 'mystical illuminations' (tajalliyat sufiya). Other poems in his new volume, such as those including a more explicit 
moral or religious message (wa'z), and those in the genre of nashid, were more optimistic and confident in their tone.

The traumatic trajectory of H.I.'s life might mislead one to read this trajectory into his writing as a sequence beginning with optimistic nashids of faith, hope, and struggle, and ending with melancholic laments of uncertainty and haze. But there is no such sequence. He has cultivated both genres throughout his career. This is a conventional part of the classical understanding of poetic skill to which H.I. subscribes: being a poet involves the command of classical forms, and the mastery of a repertoire of fixed genres and styles that each have their appropriate topics and emotional tones:

Only a true poet can write 'amudi poetry; [...] one needs to have studied and memorised, one needs to master many metres, not just one or two, and metres with a single verse foot as well as metres with several verse feet. One may master a variety of them, up to more than ten of the metres of al-Khalil. That's the one whom you can rely on as a poet.

[...]

I have written in fourteen metres. I consider the poetry [I have written in those metres] sound in regard to prosody, and the rhymes and rhythms are sound. But one is more at home in some metres rather than others. [It depends on] what I want to write: if I want to write lyrically, I find al-Wafir better than writing in al-Kamil. If I want to write something that contains a moral lesson ( $w a{ }^{\prime} z$ ), al-Kamil is better for me, or al-Basit. If I want to write something where I demonstrate my skill [as poet], then I write in the metre of al-Tawil. [...] That is, I choose the metre that suits the mood I have.

H.I. grounded poetry in the mastery of different forms and techniques, which through the right rhythm and poetic images can 'reach the heart of the audience'. He considers classical prosody 'the original ground of poetry', but his oeuvre also contains poems in the modernist style of tafila. H.I. has also written some colloquial poetry, and he told us that he once wrote song texts for a singer. He expressed pride about his command of different genres, and argued that poets need to develop and to adapt to popular taste in order to be heard.

The parallel of committed nashid and melancholic lyrics is not unique to H.I. In summer 2018, I showed H.I.'s poetry to Giedrẻ Šabasevičiūtė who had studied the literary milieus of the influential Islamist writer and ideologue Sayyid Qutb (Šabasevičiūtè 2018). According to her, the same parallel is part of the oeuvre of Sayyid Qutb as well, and is also present in the works of other contemporary poets with an Islamic conservative approach. Mystical melancholy and puzzled search for elusive certainties are not an anomaly among Islamist poets and militants. On the contrary, they are part of the emotional repertoire of an Islamist activist vision of self and world. The melancholic, doubtful side of H.I.'s work does not deny his hope for a radical yet vaguely defined better Islamic future. Rather, the two seem to go well together. 


\title{
Principled poetics of uncertainty
}

H.I. is a polite man, and knowing that our literary taste differs from his, he avoided offending our sensibilities. He was clear, however, about his rejection of experimental aesthetics:

\begin{abstract}
My aim is not to write poetry that brings a word from east and word from west in a surrealist or riddled manner. That's not clear. No, I concentrate on a specific thing I want to say, with neither content dominating over the form nor the other way around, so that the reader will grasp a specific thing, understand what I want to say. The modern direction in poetry, especially tafila poetry, is imaginations and intersections in images, and there is no meaning. Some poets of taf ila whose work I have read, they come up with stuff; you understand every sentence they write, but try and find if there's a link between the beginning and the end of the poem? You won't find it. [...] When I read such a poem, what do I profit from it? Is there anything that reaches me?
\end{abstract}

That the early twentieth-century artistic and literary school of surrealism features as H.I.'s main aesthetic adversary (it did so also in the interview in 2012) tells how conservative his literary vision is. ${ }^{5}$ Even the experimental aesthetics that he knows enough about to reject them are old. His knowledge of contemporary Arabic poetics ends with later twentieth-century modernist taf'ila. Prose poetry is too far from H.I.'s literary world to be an issue of contention for him.

H.I.'s decidedly conservative aesthetics are inseparable from his conservative moral and religious stances. Just as experimental aesthetics invite an exploration beyond the known that has moral consequences, so also conservative aesthetics invite a search for certainty and clarity. And yet the issue is not simply one of experimental uncertainty vis-à-vis conservative certainty. In a sense, the reverse is the case.

To understand how, it is helpful to compare the approaches of H.I. and Montaser Abdel Mawgoud (whose work was featured in Chapter 7). Both share a major concern for uncertainty. They often even use the same words to describe it. But their valuation of that condition, and the way the address it in poetry and life, are contrary.

Montaser argued that constant transformation and uncertainty are the new 'nature of things' that poetry needs to reflect in both form and content. His aim to explore a changing world without judgement was grounded in an underlying

5 We encountered surrealism as an aesthetic enemy in other conservative contexts as well. B.S. whom we briefly mention in Chapter 2, and who is not a supporter of the Islamist current, also took an explicit stance against surrealism. 
trust in the human capacity to adapt, adjust, and change, and a positive moral valuation of uncertainty and open-endedness. H.I., too, recognises uncertainty as the prevailing key condition, but he sees it as a problem. In his lyrical work, he embarks on a melancholic search for a truth lost. His search is grounded in the mastery of classical forms on the one hand, and a conservative commitment to societal values and faith on the other. At the end of the interview in 2017, he explained why his (unpublished) new volume of poetry was called Hymns of the Lost Dream (Taranim al-hulm al-da' $\left.i^{\prime}\right){ }^{6}$

In the whole text you will not find a certain (yaqini) truth, except where I address religious aspects. Otherwise, you will find nothing certain (yaqini) except that we will die. So the dream is ... that the human being ... for example, societal progress, change. But is that change happening or not? God knows. That's why I called the book Hymns of the Lost Dream. [...] There is nothing real. It's exactly like a mirage. And that is what most of the poems of the volume speak about. It has political, and lyrical, and religious ones. But they also do not transgress the fundamental principles that I was brought up with.

H.I.'s lyrical work has an exploratory aspect that does not fit neatly into the ethical-pedagogical project of 'art with a purpose' that has been promoted by preachers and activists of the Islamic revival (Winegar 2016). But it is essential for him that his poetry has a sincere and meaningful message to the audience.

Both poets importantly link their poetic stances with their faith in the God of the Qur'an. But they express a different understanding about what kind of relation that faith is. For Montaser, faith is subject to rethinking and revision. For H.I., it is the one certain thing in spite of all confusion. These different forms of faith link in strong ways with poetic aesthetics. Contrasting Montaser's claim that traditional forms lead to a dead end in a changing world, H.I. argues that traditional forms need to be cultivated and mastered precisely because the world is changing and full of uncertainties.

This casts a different light on the postmodern idea of uncertainty as the cause and ground for open-ended exploration that was developed by Montaser Abdel Mawgoud in Chapter 7. For H.I. and others like him, the 'stock of certainty' evoked by Montaser in relation to established poetic forms is highly desirable but is not easily available. For one thing, it requires learning and cultivation - of both a technical and moral kind. Furthermore, a principled search for objective certainties (thawabit) and clear vision can make one more sensitive to uncertainties and doubts.

6 By the time of writing in summer 2020, the volume is still unpublished because H.I. has not had enough money to pay for its printing. 
Most other supporters of Islamist movements whom we have met during our fieldwork have not spoken of such deep crises of trust, although many have quite openly addressed various doubts and tensions they live with. Such tensions do not have to be an obstacle for activist striving - on the contrary, the experience of contradictions and failures can be motivating (Beekers and Kloos 2018), and meaningful struggle can in itself be the best way to maintain a sense (or illusion) of consistency (Ewing 1990). In comparison, H.I. appears exceptionally principled, which makes him also exceptionally sensitive of inconsistencies. Where others may see opportunities in a tactical battle, H.I. sees a confusion where right and wrong look suspiciously alike.

Some other people previously active in Islamist milieus whom we know and who have faced such deep crises as the one H.I. faced, have ended up abandoning not only the organisations but also their ideologies, some even their religious faith and identity. Their path appears out of the question for H.I. For him, the contrast he perceives between principles and politics has discredited politics but not the principles.

Not so paradoxically, then, H.I. appears more doubtful than Montaser. Uncertainty is a problem for him, troubling but also productive. He keeps exploring it in his lyrical work. It appears as a constant line in his oeuvre from the early $1990 \mathrm{~s}$ until 2017. And he explicitly affirms its importance. Puzzlement, confusion, and uncertainty thus appear as a productive conflict that sharpens his sensibilities and vision - and because of his highly principled ambitions, he sees haze.

\section{A romantic common ground}

H.I.'s trajectory and oeuvre are an important reminder that conservative aesthetics, ethics, and politics are often not simply based on a taken-for-granted stock of certainties, but rather can involve much uncertainty, doubt, and work towards certainties that are not easily had. They are also a reminder that one of the most important and compelling critiques towards Islamist movements is not that they are too rigid and radical, but on the contrary that they compromise their radical promises. Last but not least, they are a reminder of a longer history of political violence that marks the lives and imaginations of so many contemporary Egyptians. The 25 January revolution did not emerge from out of nowhere after a decades-long period of calm: it was preceded by other uprisings. But the uprising of the Gama'a al-Islamiya in the 1990s was so violent and devastating that non-Islamists rarely if ever think of it as a predecessor of 2011, and even former or present 
supporters of militant Islamist movements seldom remember it in heroic or nostalgic colours.

However, my account of our encounter with H.I. is not yet complete. As it stands, it is too binary to be true, juxtaposing H.I. the doubtful conservative traditionalist with Montaser the curious and experimental postmodernist, as if these were the only alternatives and as if they did not share much. Other chapters of this book show that there are many more - and more likely - options. Furthermore, the two men and their works have important features in common.

Between the two authors, there are vast literary mainstreams of commercial and highbrow novels, and colloquial and modernist poetry, which neither call into question key societal and spiritual certainties, nor lament the lost vision of radical religious politics. H.I. and Montaser are both outsiders to these mainstreams, their positions extreme and their aesthetics unpopular (one too experimental, the other too classical). They should therefore not be taken as exemplary for anything but themselves. Rather, they mark the limits of the literary mainstreams. And by so doing, they help us appreciate the common ground they share.

First, they share a generational experience and class position. Born in the early 1970s, they are almost exactly the same age. They both come from provincial locations (H.I. from a village in Upper Egypt, Montaser from a town in the Nile Delta) and moved to Alexandria in their early adulthood. They have the same educational degrees, and until 2016, they did the same work as teachers of Arabic and Islam in government schools. Even their early literary socialisation was similar - both were initially introduced to classical forms and twentieth-century modernism, and had their first encounters with literary scenes at cultural centres and the Writers' Union in the early 1990s. Only from there did their paths take different routes. Montaser went on to become an experimental poet active in the emerging independent scene, and gained national and international connections with like-minded people. H.I. might have continued on the path of a part-time writer recognised and appreciated by peers in the public-sector scene, but this path was interrupted, with traumatic consequences. Later, H.I. recovered a degree of material stability as a schoolteacher, while the stability of Montaser's life was shattered and he had to emigrate. Today, the two men's positions and stances are different in many ways, but their trajectories are within a range available in their social milieu and generation. They do not belong to different worlds.

Second, while they both have an experience of marginality and oppression for different reasons and by different powers - they also share a confidence about being part of the proper field of literature, and search to be heard and recognised in that capacity.

H.I.'s work would almost certainly not be appreciated in the internationally connected avant-garde that helped out Montaser when the latter got into trouble. 
And yet H.I. did not complain to us about marginalisation. He spoke about oppression. He is marked as an outsider by politics, not by his aesthetics. In fact, he does not feel at all marginalised vis-à-vis the literary scene. When he started writing again in around 2014, he also started frequenting symposiums, and has since then re-established his old network with writer friends from his younger years. H.I.'s vision and knowledge of literature are structured by a bubble that confirms its own centrality as representing unmarked 'literature'.

Montaser, in contrast, enjoys the privilege of proximity to the international network of secular avant-gardes that have opened for him possibilities of travel and translation that are inaccessible to H.I. But while H.I. expresses no sense of antagonism towards the society in which he lives - in fact, he is explicitly pro-society, a supporter of conservative values that he sees embodied by Upper Egyptian society in particular - Montaser has found himself repeatedly at odds with his society, of which he is explicitly critical. He had to leave his work, home, and finally his country not because he feared oppression by the state, but because he feared his neighbours and colleagues at work. And while his poetry was heavily contested by the latter, he found support and confirmation from people in the literary scenes he frequented, which allowed him, too, to understand himself as part of unmarked 'literature', as opposed to schoolteachers and religious radicals who, in his view, do not know how to read a literary work.

Literature today is a vast social institution that can encompass contrary approaches and mutually exclusive claims. Controversies and attempts at censorship proliferate, and mutual non-recognition is the order of the day, and yet in the past couple of decades at least, no literary milieu has been successful in dominating others. Only some of them are likely to gain recognition in Europe and Northern America as 'world literature', only some produce texts that may be recognised and supported as poetry by conservative Arabic-speaking networks, and only some provide opportunities for commercial success. And so on. Together, they allow their participants to make claims to status and authority, to demand that their voice is heard, and to enjoy a limited freedom to act and think in unusual, even strange, ways - but it is a freedom demarcated by real and hard limits of violence, as H.I.'s years in prison and Montaser's forced emigration remind us.

Third, the two men share what I call a romantic literary subjectivity. And it is not only them: a romantic theory of the author-subject is an important common ground that unites otherwise highly different, even mutually opposed ideas and ways of literary production in Alexandria and Egypt in the early twenty-first century.

The key idea of romantic subjectivity is that a person's experience and subjective positionality are the ground from which literary texts, artistic positions, and also political stances emerge. It is so commonplace today that it becomes 
best recognisable in historical comparison (which we provide in more detail in Chapter 1). Arabic poetry has paid great attention to authorship as long as written records can tell, and the names of early Arabic poets are transmitted along with their works. Contemporary readers may read the love poetry attributed to Majnun Leyla as an expression of his subjective feelings and positionality in a tribal society that would not allow for his marriage with Leyla (tellingly, though, Leyla's voice remains unheard in the story). And yet the poetry attributed to Majnun probably consists of works by different authors who worked on the same theme (Khan 2019). Throughout the history of pre-modern Arabic poetry and adab, it was common that writers would attribute their works to other, more famous, authors, or claim them to be translations instead of original works. Authorship was about authority rather than originality, and authority could be borrowed or forged (Kilito 2001). The idea that a literary text would need to be authentic in the subjective sense of being grounded in an experience, feeling, or reflection by its author was secondary at best.

In contrast, the vast majority of the writers we have encountered in our research and featured in this book, including Montaser Abdel Mawgoud and H.I., consider writing and authorship as something inseparable from their individual subjectivity. This is most explicit in decidedly subjective texts, such as H.I.'s lyrical works. In our interviews in 2012 and 2017, H.I. repeatedly used the phrase 'true suffering', which prompted Mukhtar to ask him:

Do you mean that every creative producer (mubdi) has to suffer in order to be one?

H.I.: Well, he can also suffer from happy things; it's not just suffering from pain, but something you live and become one with, something you communicate with on a strongly emotional level.

In addition to being a reality in his life, suffering for H.I. appears as a poetic and ethical sensibility that allows him to recognise and communicate the condition of uncertainty and unclarity he faces. He elevates suffering to a poetic capacity to 'communicate on a strongly emotional level', which also means that the ground of that communication is his subjective experience and vision of the world. This is notably not a liberal idea of an autonomous and authentic self: H.I.'s valuation of suffering as a source of communication is a case in point of a highly subjective individual position that is not bounded, not autonomous, but rather receptive and exposed to divine and human powers. This does not make it less individualistic and romantically subjective, however, highlighting as it does his unique capacity to translate a specific suffering into a meaningful communication.

Montaser's poetry is not dominated by his biography the way H.I.'s is, and when he discusses his works he does not attribute them to specific events in his 
life. On the contrary, he consciously strives to produce autonomous texts that can stand by themselves, that are not extensions of his ego or superego (similar to the approach promoted at Alshimaa Hamed's workshop in Chapter 3 where Montaser was once a guest speaker). And yet in the interview in 2017, Montaser told us he had abandoned classical and early modernist poetic forms because they were not 'what I wanted to bring from within me', thus implying a link between experimentation and subjective expression. Montaser also argued that his spiritual explorations in his third volume of poetry, There Are Things He Will Not Try (Abdel Mawgoud 2012), are indeed his own, that is, they are the outcome of an individual and individualistic search where his subjective position towards God, revelation, and language results in a new arrangement of the relationship. This is also explicit in the original working title of the volume, The Bible Written by $\mathrm{Me}$. Last but not least, in his third volume, Montaser systematically depicts God, prophets, and angels as romantic subjects: unique and sensible, driven by a combination of interiority and experience. This was controversial not because such romantic subjectivity would be alien to even the most conservative readers, but rather because he broke a dividing line that bans the faithful from imagining God, angels, and prophets in the same ways in which they may ordinarily imagine humans who are not prophets, saints, religious heroes, or leaders.

Thus, our exploration that began with our abandonment of the question of individual motivations to write (in Chapter 1) and therefore compelled us shift our focus to literature as a social and relational practice, has finally brought us back to the issue of individuality - but now not as something taken-for-granted, but rather as a peculiar historical artefact that is shared by writers and writings of an era across the spectrum, even when they may be different in numerous other ways. 
